\title{
Living with the enemy: activity rhythms of the red fox Vulpes vulpes (Carnivora, Canidae) and some potential preys in an urban environment
}

\author{
Alessandro Nardotto
}

\begin{abstract}
The present study aimed at investigating the activity rhythms of the red fox Vulpes vulpes and three potential preys (i.e. the European hedgehog Erinaceus europaeus, the wood mouse Apodemus sylvaticus, and the Norway rat Rattus norvegicus) in an urban environment. Data were collected as a part of a camera trapping survey, carried out within the municipality of Padua (northeastern Italy). In order to analyse species activity patterns, the $\mathrm{R}$ overlap package was used and then the Watson-Wheeler test was run to evaluate whether two overlaps were significantly different. Results show that all the investigated species have nocturnal activities, with "moderate" temporal activity overlap between the red fox and its potential prey. The Watson-Wheeler test showed that the hedgehog was the only potential prey that did not show significant differences in the hours of activity compared to those of the red fox. Instead, statistically significant differences were recorded when the activity rhythm of the red fox was compared with that of the wood mouse or the Norway rat. This may indicate the development of antipredator behaviour or the possibility that the red fox is seeking anthropogenic food sources instead of wild prey or, alternatively, other preferred food items.
\end{abstract}

Keywords: activity rhythms, camera trapping, prey-predator interactions, red fox, temporal activity overlap, urban ecology.

Riassunto - Vivere con il nemico: ritmi di attività della volpe rossa Vulpes vulpes (Carnivora, Canidae) e di alcune potenziali prede in un ambiente urbano.

Questo studio si propone di indagare i ritmi di attività della volpe rossa Vulpes vulpes e di tre potenziali prede (il riccio europeo Erinaceus europaeus, il topo dei boschi Apodemus sylvaticus e il ratto delle chiaviche Rattus norvegicus) in un ambiente urbano. I dati sono stati raccolti nell'ambito di un'indagine con trappolaggio fotografico, condotta nel comune di Padova (Italia nord-orientale). Per analizzare i modelli di attività delle specie, è stato utilizzato il pacchetto R overlap e poi è stato eseguito il test di Watson-Wheeler per valutare se due sovrapposizioni erano significativamente diverse. I risultati mostrano che tutte le specie studiate hanno attività notturne, con una sovrapposizione temporale "moderata" tra la volpe rossa e le sue potenziali prede. I risultati mostrano che tutte le specie studiate hanno attività notturna, con una "moderata" sovrapposizione temporale di attività tra la volpe rossa e le sue potenziali prede. Il

Via Guizze 55/3, 31020 Villorba (TV), Italia.

E-mail: alenard8@gmail.com

(C) 2022 Alessandro Nardotto

Received for publication: 11 June 2021

Accepted for publication: 10 November 2021

Online publication: 18 March 2022 test di Watson-Wheeler ha mostrato che il riccio era l'unica potenziale preda che non mostrava differenze significative nelle ore di attività rispetto a quelle della volpe rossa. All'opposto, sono state registrate differenze statisticamente significative quando il ritmo di attività della volpe rossa è stato confrontato con quello del topo dei boschi o del ratto delle chiaviche. Questo può indicare lo sviluppo di un comportamento antipredatorio o la possibilità che la volpe rossa cerchi fonti di cibo antropogeniche invece di prede selvatiche o, in alternativa, altri alimenti preferiti.

Parole chiave - ecologia urbana, interazioni preda-predatore, ritmi di attività, sovrapposizione temporale di attività, trappolaggio fotografico, volpe rossa.

\section{INTRODUCTION}

Many animal species have adapted well to life in anthropised contexts and lacking in natural elements (Luniak, 2004; Adams, 2005; McCleery et al., 2014). Among these species, various small mammals and their predators, such as the red fox Vulpes vulpes, occur in Europe (Luniak, 2004). In urbanised contexts, we might expect a shift in the pattern of animal activity during the night, when anthropogenic disturbance and human presence are minimised. This implies that prey and predators are both active mainly at night and during twilight hours, with almost similar and overlapping rhythms of activity. Despite this, a diversity of factors can influence diel activity levels in mammals, often leading to unexpected breakthroughs in research (Monterroso et al., 2014; Sogliani et al., 2021). For instance, prey species of domestic origin can switch their activity patterns to hours associated with a more intense anthropic presence to reduce the risk of predation (Sogliani et al., 2021), while other species can modulate their density of activity at specific hours to thermoregulate (Terrien et al., 2011; Milling et al., 2017). In this regard, studies on the activity rhythms are very useful to understand the dynamics that regulate prey-predator relationships (Monterroso et al., 2013; Lang et al., 2019; Viviano et al., 2021) as well as the factors shaping behavioural choices (Monterroso et al., 2013). In this context, this study aims to investigate how much overlap there is between the activity patterns of the red fox and three potential preys, the European hedgehog Erinaceus europaeus, the wood mouse Apodemus sylvaticus and the Norway rat Rattus norvegicus, in an urban environment. 


\section{MATERIAL AND METHODS \\ Study area}

The study area is enclosed within the administrative boundaries of the Municipality of Padua (Fig. 1). The municipal territory extends for $93.03 \mathrm{~km}^{2}$ and is located in the central-western part of the Venetian plain. Padua, the most densely populated municipality of the Veneto region (ISTAT), is characterized by a high degree of anthropization, with $62.6 \mathrm{~km}^{2}$ of "artificial surfaces" (code " 1 " of the first level of the Corine Land Cover classification). Despite the prevalence of urban and industrial fabric, some valuable natural environments are still present. In particular, the various waterways that cross the municipal area, still bordered by riparian vegetation, represent valuable biodiversity reserves for the urban ecosystem. Other elements of moderate naturalistic value include fallow lands, private gardens, tree patches, ruins and ditches. The remaining wooded areas are mainly represented by forest formations of anthropic origin, such as the black locust Robinia pseudoacacia L. groves and the industrial plantations of various clones of Canadian poplar Populus nigra L. $\times$ Populus deltoides (Marshall) W. Bartram. Even if these forested areas are characterized by modest extension, simple composition and uniplanar vertical development, they anyway represent potential shelterbelts and buffer zones for several species of birds, mammals and other animals.

\section{Data collection and analysis}

The data collected in this study were obtained with camera trapping (Rovero \& Zimmerman, 2016; Wearn \& Glover-Kapfer, 2019), a technique widely used to evalua- te the activity rhythms of vertebrates (Lashley et al., 2018; Andreoni et al., 2020; Mori et al., 2020, Sogliani et al., 2021). In particular, four camera traps (Apeman H55 20 $\mathrm{mp}, N=2$; DIGITNOW Trail Camera $16 \mathrm{MP}, N=2$ ) were used in the study. Camera traps have been set in photo mode with a 15 -second interval, thus minimising the time between shots and gaining battery life. Cameras, active $24 \mathrm{~h} /$ day, were arranged in eight camera-trap stations and placed at a height of $30-70 \mathrm{~cm}$ from the ground. Stations were chosen based on accessibility and habitat suitability, preferring the edges of riparian vegetation or areas covered with trees and shrubs. Cameras were checked every ten days during two camera trapping sessions in 2021 the first lasted from February 16 to April 15, involving an initial set of four camera trapping stations, and the second from April 15 to May 26, involving a further four camera trapping stations. In particular, the chronological information obtained from the camera traps was used to compute activity rhythms for the following species coexisting in five out of the eight stations: Apodemus sylvaticus, Rattus norvegicus, Erinaceus europaeus and Vulpes vulpes. Camera trapping provided more than 30 independent observations for each species, permitting a reliable analysis of the activity rhythms (Lashley et al., 2018). Analyses of activity rhythms and pairwise comparisons of temporal activity overlap were performed using $\mathrm{R}$ software (version 4.0.2; R Core Team, 2020) and the package overlap (Meredith \& Ridout, 2014). To compare activity rhythms, the overlap coefficient $(\Delta)$ and the related $95 \%$ confidence intervals were calculated. The coefficient assumes values ranging from 0 (no overlap) to 1 (total overlap: Meredith \& Ridout, 2014; Mori et al., 2020). The overlap is consi-

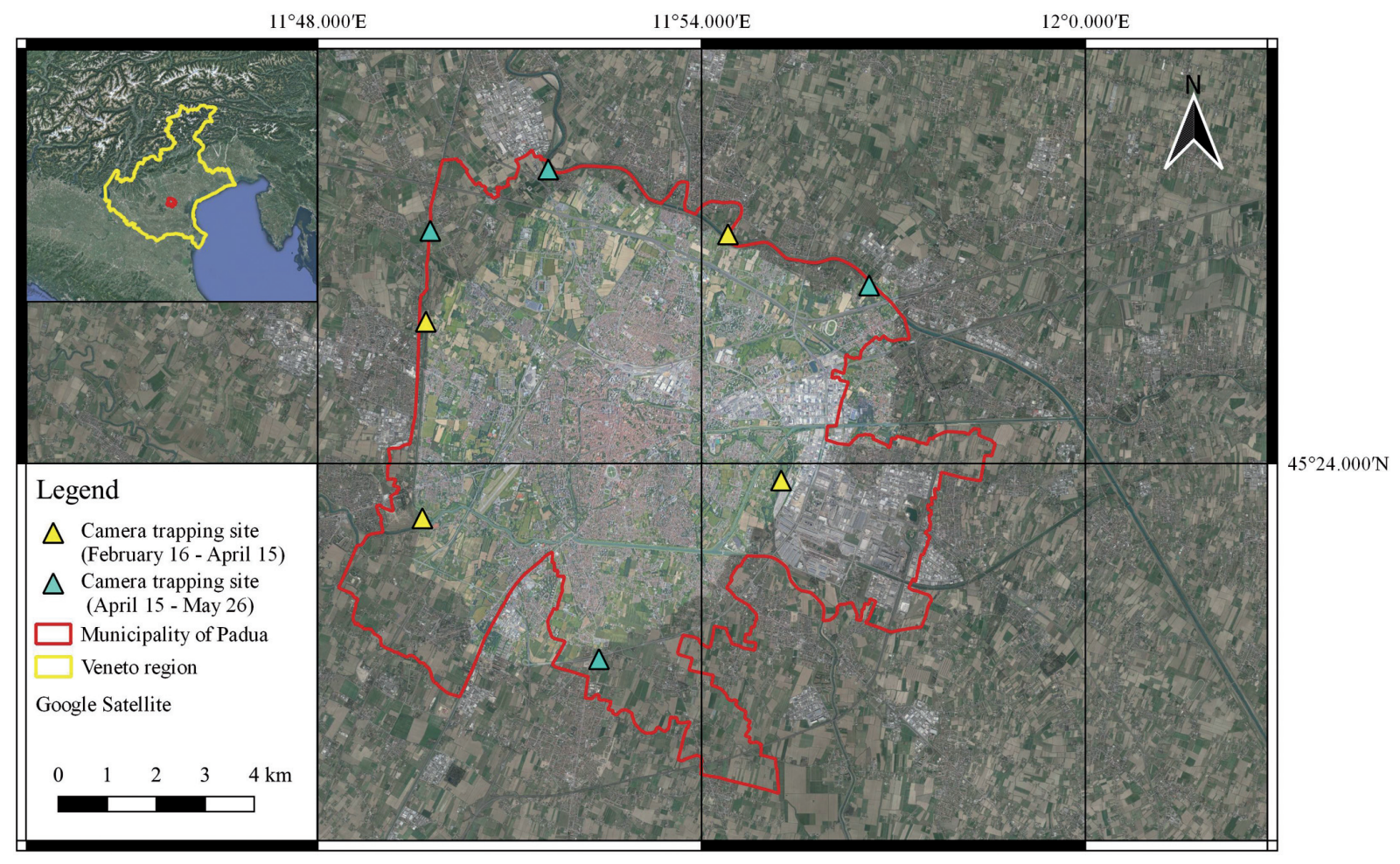

Fig. 1 - Satellite view of the municipal area of Padua and location of the camera traps. / Immagine satellitare del territorio comunale di Padova e posizione delle trappole fotografiche (Image/Immagine: Google Satellite). 
dered "moderate" when $0.50 \leq \Delta \leq 0.75$, "high" when $\Delta$ $>0.75$ and "very high" when $\Delta>0.90$ (Monterroso et al., 2014; Mori et al., 2020). If the records collected for one of the two species included in the comparison were less than 75 , the calculation of the overlap requires the use of estimator $\Delta_{1}$; otherwise, in case the records for both species are greater than 75 , the estimator $\Delta_{4}$ was used (Linkie \& Ridout, 2011; Monterroso et al., 2014). Since the value of $\Delta$ is purely descriptive, the Watson-Wheeler test (Batschelet, 1981; Monterroso et al., 2014), a homogeneity test on two or more circular data samples, was performed to assess whether two overlaps are significantly different. The operation was performed in $\mathrm{R}$, using the circular package (Lund et al., 2017).

\section{RESULTS}

Survey effort totalled 396 camera trapping nights (i.e. number of camera traps $\times$ days of activation). Altogether, 132 red fox, 224 hedgehog, 48 wood mouse and 235 Norway rat records were obtained. The overlap between the activity rhythms of the fox and the possible prey is shown in Fig. 2. The activity patterns show how studied species were mainly active at twilight and night hours, avoiding daylight, typically characterized by a high anthropogenic disturbance. The calculated coefficients of temporal overlap are "moderate". The lowest value is represented by the fox-wood mouse overlap, $\Delta=0.65$; the highest instead is represented by the of the fox-hedgehog overlap, $\Delta=0.75$, close to "high" values.

Despite the "moderate" overlap values, the WatsonWheeler test (Tab. 1) showed extremely significant differences for the fox-wood mouse and fox-Norway rat pairing ( $p$-value $<0.01)$, while the fox-hedgehog pairing ( $p$-value $>0.05)$ does not show significant differences.

\section{DISCUSSION}

The analysis shows that the red fox and the three of its possible preys share a common temporal space of activity in the study area. Despite the great behavioural plasticity of the red fox, the species is generally described as nocturnal (Díaz-Ruiz et al., 2015; Moll et al., 2018, Sogliani \& Mori, 2019). The nocturnal behaviour is even more pronounced where higher levels of anthropogenic disturbance occur (Doncaster \& Macdonald, 1997; Gil-Fernández et al., 2020), such as in the Municipality of Padua. The overlapping coefficients of the activity rhythms suggest that the red fox potentially interact with the prey species considered in this study. In particular, the hedgehog did not show significant differences in the pattern of activity compared to the fox. Indeed, predation on the hedgehog seems to be rather unlikely or occasional (Murdoch et al., 2010) due to the effective defensive behaviour of this species. On the other hand, the activity patterns of the two rodents differ significantly from that of the fox (Tab. 1), despite the "moderate" overlapping in temporal activity coefficients. Thus, the two rodents exhibit activity peaks that are not aligned with those of the red fox. This is especially apparent in the activity rate of the wood mouse, the species with the lowest overlap


Fig. 2 - Temporal activity overlap between the red fox and its potential preys. The shaded area under the two density estimates represents the overlap coefficient. / Sovrapposizione dell'attività temporale tra la volpe rossa e le sue potenziali prede. L'area ombreggiata sotto le due stime di densità rappresenta il coefficiente di sovrapposizione.

Tab. 1 - Watson-Wheeler test results. Significant $p$-values are indicated with a star $(*)$. / Risultati per il test WatsonWheeler. I $p$-value significativi sono indicati con un asterisco $(*)$.

\begin{tabular}{|l|l|}
\hline \multicolumn{2}{|c|}{ WATSON-WHEELER TEST } \\
\hline Fox - Hedgehog & $\mathbf{W}=\mathbf{2 . 7 3} p$-value $=0.25$ \\
\hline Fox - Wood Mouse & $\mathbf{W}=\mathbf{2 6 . 1 0} p$-value $<0.01^{*}$ \\
\hline Fox - Norway Rat & $\mathbf{W}=\mathbf{2 6 . 5 7} p$-value $<0.01^{*}$ \\
\hline
\end{tabular}

coefficient $\left(\Delta_{1}=0.65\right)$, and can be interpreted as a potential anti-predatory behaviour. It is now well known that predation influences aspects of the biology of small mammals (Simonetti, 1989; Hanski et al. 2001, Diaz et $a l ., 2005)$ by inducing the development of physiological and behavioural strategies aimed at reducing the predation risk (Mappes \& Ylönen, 1997). Among the three prey species under examination, the wood mouse seems potentially the most accessible and preferred to the predator. However, it should also be emphasized that the activity pattern of the wood mouse could be affected by the small sample size $(N=48)$ and by other ecological factors that should be taken into consideration. For instance, the rodent behavioural response might also be triggered by free-ranging domestic cats Felis catus $(N=190)$, an efficient and specialized predator of mice detected during the survey. To confirm this hypothesis, the diet of urban red foxes and free-roaming cats should be analysed. Another factor that has to be taken into consideration is the presence of anthropogenic food sources (such as garbage dumps, vegetable gardens, chicken coops), quite common in the study area. Anthropogenic food sources can greatly influence the red fox feeding ecology, having the potential to replace largely the consumption of wild prey (Reshamwala et al., 2018; Gil-Fernández et al., 2020). If so, the predator may have shifted its activity pattern in re- 
lation to the minor human presence at night and the increased availability of abundant and easily accessible food items, rather than calibrating its temporal activity to that of potential wild prey. These hypotheses could support the observed opportunistic feeding behaviour of the red fox (Sogliani \& Mori, 2019) and, possibly, a tendency to avoid human disturbance (Díaz-Ruiz et al., 2015).

\section{CONCLUSIONS}

The study demonstrated how in an urban habitat such as that of the Municipality of Padua, the red fox and some of its preys are predominantly active at night. Through the analysis of temporal activity overlaps between the fox and its potential prey, it was possible to study predator-prey interactions and to understand whether and when the species are active at the same time. In fact, some predators, in some situations, adapt their period of activity in order to match that of their main prey, thus reducing the foraging effort (Monterroso et al., 2013). Finally, camera trapping has proved its value as a useful technique for analysing mammalian activity patterns also in an urban habitat and for small mammals not usually studied with this methodology. The research also led to the formulation of further working hypotheses that could improve our understanding of the species studied and their ecological, spatial and behavioural dynamics in an urban setting.

\section{REFERENCES}

Adams L., 2005 - Urban wildlife ecology and conservation: A brief history of the discipline. Urban ecosystems, 8 (2): 139-156. $<$ doi:10.1007/s11252-005-4377-7>

Andreoni A., Augugliaro C., Zozzoli R., Dartora F. \& Mori E., 2020 Diel activity patterns and overlap between Eurasian red squirrels and Siberian chipmunks in native and introduced ranges. Ethology Ecology \& Evolution, 33 (1): 83-89.

Batschelet E., 1981 - Circular Statistics in Biology. Academic Press, London, New York.

Díaz M., Torre I., Peris A. \& Tena L., 2005 - Foraging Behavior of Wood Mice as Related to Presence and Activity of Genets. Journal of mammalogy, 86: 1178-1185.

Díaz-Ruiz F., Caro J., Delibes-Mateos M., Arroyo B. \& Ferreras P., 2015 - Drivers of red fox (Vulpes vulpes) daily activity: prey availability, human disturbance or habitat structure? Journal of zoology, 298 (2): 128-138.

Doncaster C. P. \& Macdonald D. W., 1997 - Activity patterns and interactions of red foxes (Vulpes vulpes) in Oxford city. Journal of Zoology, 241 (1): 73-87. <https://doi.org/10.1111/j.14697998.1997.tb05500.x>

Gil-Fernández M., Harcourt R., Newsome T., Towerton A. \& Carthey A., 2020 - Adaptations of the red fox (Vulpes vulpes) to urban environments in Sydney, Australia. Journal of urban ecology, 6 (1): 1-9. < https://doi.org/10.1093/jue/juaa009>

Hanski I., Henttonen H., Korpimäki E., Oksanen L. \& Turchin P., 2001 Small-rodent dynamics and predation Ecology, 82 (6): 1505-1520.

Lang S., Mann R. \& Farine D., 2019 - Temporal activity patterns of predators and prey across broad geographic scales. Behavioral Ecology, 30 (1): 172-180. <https://doi.org/10.1093/beheco/ary133>

Lashley M. A., Cove M. V., Chitwood M. C., Penido G., Gardner B., De Perno C. S. \& Moorman C. E., 2018 - Estimating wildlife activity curves: comparison of methods and sample size. Scientific Reports, $8: 1-11$.

Linkie M. \& Ridout M. S., 2011 - Assessing tiger-prey interactions in Sumatran rainforests. Journal of Zoology, 284 (3): 224-229. $<$ https://doi.org/10.1111/j.1469-7998.2011.00801.x>
Luniak M., 2004 - Synurbization-adaptation of animal wildlife to urban development. In: Proceedings $4^{\text {th }}$ International Urban Wildlife Symposium. W. W. Shaw, L. K. Harris \& L. Vandruff (eds.). School of natural resources, College of agriculture and life sciences, The University of Arizona, Tucson: 50-55.

Lund U., Agostinelli C., Arai H., Gagliardi A., Portugues E. G., Giunchi D., Irisson J. O., Pocernich M. \& Rotolo F., 2017 - Package circular. $<$ https://mirro rs.ucr.ac.cr/CRAN $>$

Mappes T. \& Ylönen H., 1997 - Reproductive effort of female bank voles in a risky environment. Evolutionary ecology, 11: 591-598.

McCleery R. A., Moorman C. E. \& Nils Peterson M. (eds.), 2014 Urban wildlife conservation. Springer.

Merdith M. \& Ridout M., 2014 - Overview of the overlap package. $<$ https://cran.cs.wwu.edu/web/packa ges/overl ap/vigne ttes/ overlap.pdf $>$

Milling C., Rachlow J. L., Johnson T. R., Forbey J. S. \& Shipley L. A, 2017 - Seasonal variation in behavioral thermoregulation and predator avoidance in a small mammal. Behavioral Ecology, 28 (5): 1236-1247. <https://doi.org/10.1093/beheco/arx084>

Moll R. J., Cepek J. D., Lorch P. D., Dennis P. M., Robison T., Millspaugh J. J. \& Montgomery R. A., 2018 - Humans and urban development mediate the sympatry of competing carnivores. Urban ecosystems, 21: 765-778. <https://doi.org/10.1007/s11252-018-0758-6>

Monterroso P., Alves P. \& Ferreras P., 2013 - Catch Me If You Can: Diel Activity Patterns of Mammalian Prey and Predators. Ethology, 119: 1044-1056. <https://doi.org/10.1111/eth.12156>

Monterroso P., Alves P. C. \& Ferreras P., 2014 - Plasticity in circadian activity patterns of mesocarnivores in southwestern Europe: implications for species coexistence. Behavioral Ecology and Sociobiology, 68: 1403-1417.

Mori E., Andreoni A., Cecere F., Magi M. \& Lazzeri L., 2020 - Patterns of activity rhythms of invasive coypus Myocastor coypus inferred through camera-trapping. Mammalian biology, 100: 591-599.

Murdoch J., Tserendorj M., Suuri B., Reading R. \& Sillero C., 2010 Seasonal food habits of corsac and red foxes in Mongolia and the potential for competition. Mammalian biology, 75: 36-44. $<$ doi:10.1016/j.mambio.2008.12.003>

R Core Team, 2020 - R: A language and environment for statistical computing. R Foundation for Statistical Computing, Wien, Austria. $<$ https://www.R-project.org/>

Reshamwala H., Shrotriya S., Bora B., Lyngdoh S., Dirzo R. \& Habib B., 2018 - Anthropogenic food subsidies change the pattern of red fox diet and occurrence across Trans-Himalayas, India. Journal of Arid enviroments, 150: 15-20. <https://doi.org/10.1016/j. jaridenv.2017.12.011>

Rovero F. \& Zimmermann F., 2016 - Camera Trapping for Wildlife Research. Pelagic Publishing, Exeter, UK.

Simonetti J. A., 1989 - Microhabitat use by small mammals in central Chile. Oikos, 56: 309-318.

Sogliani D. \& Mori E., 2019 - "The Fox and the Cat": Sometimes they do not agree. Mammalian Biology, 95: 150-154. <https://doi. org/10.1016/j.mambio.2018.07.003>

Sogliani D., Cerri J., Turetta R., Crema M., Corsini M. \& Mori E., 2021 Feral rabbit populations in a peri-urban area: insights about invasion dynamics and potential management strategies. European Journal of Wildlife Research, 67: 60. <https://doi.org/10.1007/s10344-02101505-2>

Terrien J., Perret M. \& Aujard F., 2011 - Behavioral thermoregulation in mammals: A review. Frontiers in bioscience, 16 (4): 1428-1444. $<$ https://doi.org/10.2741/3797>

Viviano A., Mori E., Fattorini N., Mazza G., Lazzeri L., Panichi A., Strianese L. \& Mohamed W. F., 2021 - Spatiotemporal Overlap between the European Brown Hare and Its Potential Predators and Competitors. Animals. 11 (2): 562. <https://doi.org/10.3390/ ani11020562>

Wearn O. R. \& Glover-Kapfer P., 2019 - Snap happy: camera traps are an effective sampling tool when compared with alternative methods. Royal Society Open Science, 6 (3). <https://doi.org/10.1098/ rsos.181748> 